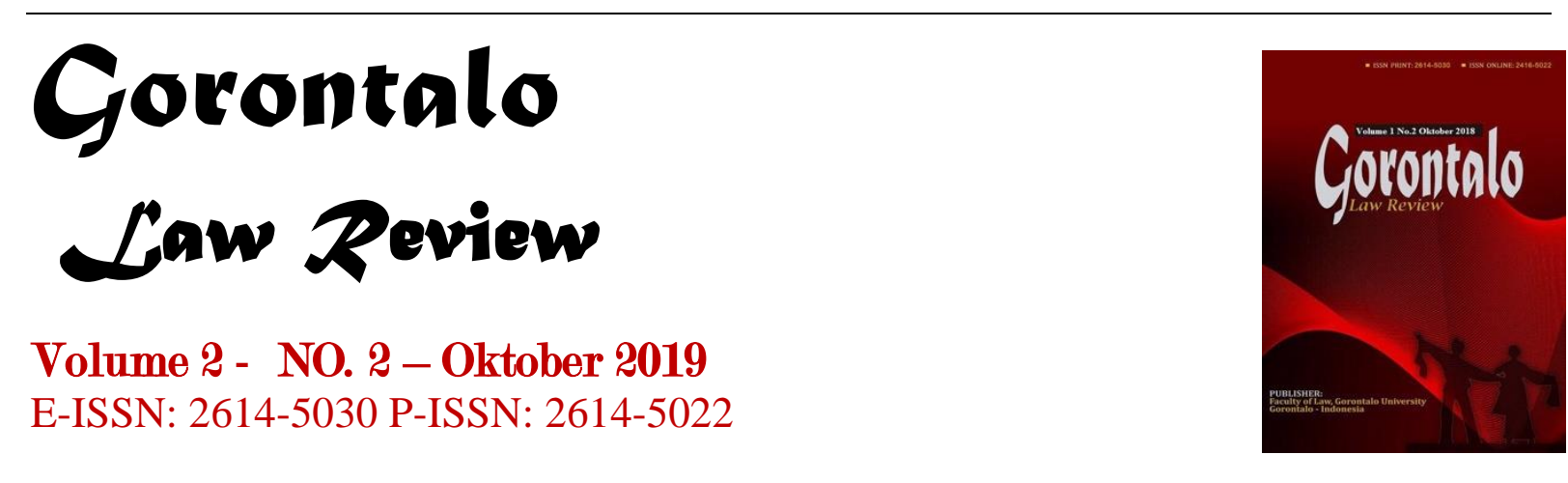

\title{
PENERAPAN PRINSIP MENGENAL NASABAH SEBAGAI UPAYA PENCEGAHAN PENCUCIAN UANG PADA PERUSAHAAN ASURANSI
}

\author{
Nashiba Maulidya \\ Fakultas Hukum Universitas Hasanuddin \\ dizzissdyeah@gmail.com \\ Nurfaidah Said \\ Fakultas Hukum Universitas Hasanuddin \\ muhammadilhamarisaputra@gmail.com \\ Sabir Alwy \\ Fakultas Hukum Universitas Hasanuddin \\ muhammadilhamarisaputra@yahoo.com \\ Muhammad Ilham Arisaputra \\ Fakultas Hukum Universitas Hasanuddin \\ ilhamarisaputra@gmail.com
}

\begin{abstract}
Abstrak
Ada satu prinsip mendasar yang harus diperhatikan dalam implementasi lembaga keuangan di Indonesia, yaitu Prinsip Mengenal Nasabah. Penerapan prinsip mengenal pelanggan Anda untuk perusahaan asuransi secara khusus diatur dalam Peraturan Ketua Badan Pengawas Pasar Modal dan Lembaga Keuangan (Bapepam dan LK) Nomor Per-01 / BL 2011 tentang Pedoman Prinsip Mengenal Pelanggan Anda Pedoman Pelaksanaan untuk Perusahaan Asuransi. Setiap perusahaan asuransi diharuskan membuat Pedoman Prinsip Mengenal Nasabah dan SOP Anda untuk mengetahui dan menganalisis calon pelanggan dan memantau transaksi yang dilakukan oleh pelanggan mereka. Penerapan prinsip mengetahui pelanggan adalah bentuk perlindungan hukum preventif dalam upaya mencegah pencucian uang dari perusahaan jasa keuangan.
\end{abstract}

Kata Kunci: Perusahaan Asuransi; Kenali Prinsip Pelanggan Anda; Pencucian Uang. 


\begin{abstract}
There is one fundamental principle that must be considered in the implementation of financial institutions in Indonesia, namely the Know Your Customer Principle. The application of know your customer principles to insurance companies is specifically regulated in the Regulation of the Chairperson of the Capital Market and Financial Institution Supervisory Agency (Bapepam and LK) Number Per-O1/BL 2011 concerning Know Your Customer Principles Implementation Guidelines for Insurance Companies. Every insurance company is required to make the Know Your Customer Principles Guidelines and SOP to know and analyze prospective customers and monitor transactions carried out by their customers. The application of the principle of knowing customers is a form of preventive legal protection in an effort to prevent money laundering from occurring in financial service companies.
\end{abstract}

\title{
Keywords: Insurance Companies, Know Your Customer Principles, Money Laundering.
}

\section{PENDAHULUAN}

Tindak pidana pencucian uang pada awalnya diatur dalam Undang-Undang Nomor 15 Tahun 2002 tentang Tindak Pidana Pencucian Uang yang kemudian diubah dengan Undang-Undang Nomor 25 Tahun 2003 tentang Perubahan Atas UndangUndang Nomor 15 Tahun 2002 tentang Tindak Pidana Pencucian Uang dan terakhir diubah dengan Undang-Undang Nomor 8 Tahun 2010 tentang Pencegahan dan Pemberantasan Tindak Pidana Pencucian Uang (selanjutnya disebut Undang-Undang Tindak Pidana Pencucian Uang). Pencucian Uang tidak lain dari suatu aspek perbuatan kriminal karena sifat kriminalitasnya yang berkaitan dengan latar belakang dari perolehan sejumlah uang yang sifatnya gelap, haram, atau kotor. Kemudian sejumlah uang kotor ini dikelola dengan aktivitas-aktivitas tertentu seperti dengan membentuk usaha, mentransfer, atau mengkonversikannya ke bank atau valuta asing bahkan dengan modus asuransi sebagai langkah untuk menghilangkan latar belakang dari dana kotor tersebut.

Kegiatan pencucian uang sering melibatkan perbankan karena adanya globalisasi perbankan sehingga melalui sistem pembayaran terutama yang bersifat elektronik (electronic funds transfer), dana hasil kejahatan yang pada umumnya dalam jumlah besar akan mengalir atau bahkan bergerak melampaui batas negara dengan memanfaatkan faktor rahasia bank yang umumnya dijunjung tinggi oleh perbankan. Demikian pula tidak hanya aspek hukum yang terkait dari kejahatan ini, tetapi juga aspek non hukum lainnya seperti ekonomi, politik, dan sosial budaya.

Terdapat salah satu prinsip mendasar yang harus diperhatikan dalam penyelenggaraan lembaga keuangan di Indonesia, yakni Prinsip Mengenal Nasabah (Know Your Customer Principles). Prinsip ini pertama kali dikenal dan diatur dalam Peraturan Bank Indonesia (PBI) Nomor 3/10/PBI/2001 tentang Penerapan Prinsip Mengenal Nasabah (Know Your Customer Principles) sebagaimana terakhir diubah dengan Peraturan Bank Indonesia (PBI) Nomor 5/21/PBI/2003 tentang Perubahan Kedua Atas Peraturan Bank Indonesia Nomor 3/10/PBI/2001 tentang Penerapan Prinsip Mengenal Nasabah (Know Your Customer Principles). Dalam Pasal 1 angka 2 dijelaskan bahwa Prinsip Mengenal Nasabah adalah prinsip yang diterapkan Bank untuk mengetahui identitas nasabah, memantau kegiatan transaksi nasabah termasuk pelaporan transaksi yang mencurigakan. Ketentuan-ketentuan yang dikeluarkan oleh Bank Indonesia dan Otoritas Jasa Keuangan ditujukan untuk meredam berbagai kejahatan yang dapat timbul dalam dunia perbankan dan lembaga keuangan lainnya, khususnya tindak pidana pencucian uang yang sangat rentan dapat dilakukan oleh nasabah. 
Pentingnya prinsip mengenal nasabah memang tidak dapat dipungkiri dalam lembaga keuangan bank maupun non bank. Prinsip mengenal nasabah merupakan prinsip yang diterapkan oleh lembaga keuangan bank dan non bank. Tujuannya untuk mengetahui latar belakang dan identitas nasabah, memantau rekening dan transaksi nasabah. Selain itu juga untuk melaporkan transaksi keuangan mencurigakan dan transaksi keuangan yang dilakukan secara tunai.

Untuk mengontrol dan mengawasi kinerja lembaga keuangan, di Indonesia dibentuk lembaga Pusat Pelaporan Analisis Transaksi Keuangan (PPATK). Kehadiran PPATK diharapkan dapat mencegah kegiatan pencucian uang melalui Penyedia Jasa Keuangan. Undang-Undang Tindak Pidana Pencucian Uang memperkuat tugas, fungsi, dan wewenang PPATK dalam pencegahan tindak pidana pencucian uang. PPATK bekerjasama dengan Otoritas Jasa Keuangan (OJK) dapat melakukan pengawasan transaksi dan audit terhadap lembaga keuangan, baik perbankan dan non perbankan.

Beberapa kasus yang merupakan tindak pidana pencucian uang melalui lembaga keuangan telah banyak terjadi di Indonesia, khususnya pada lembaga perbankan. Misalnya saja kasus penggelapan dana PT Elnusa dan Pemerintah Daerah Batu Bara Sumatera Utara di Bank Mega dimana uang hasil pembobolan dimasukkan dalam perusahaan lain. (Priyambodo, $\mathrm{RH}$, www.antarnews.com)

Selanjutnya Yunus Husain menyebutkan bahwa Laporan Transaksi Keuangan Mencurigakan (LKTM) masih tetap didominasi oleh perbankan sekitar 69,1 persen, perusahaan valuta asing 19,7 persen, dan perusahaan efek sebanyak 17,16 persen. Hingga Desember 2008, sebanyak 135 Penyedia Jasa Keuangan (PJK) berbentuk bank dan 109 Penyedia Jasa Keuangan (PJK) non bank telah menyampaikan 23.056 LKTM. Sedangkan Laporan Transaksi Keuangan Tunai (LTKT) yang diterima oleh PPATK berjumlah 6.387.270. (Gusti Grehenson, https;//ugm.ac.id)

Tindak Pidana Pencucian uang di lembaga asuransi lebih memungkinkan terjadi. Contoh kasus tindak pidana pencucian uang sebesar Rp. 11.400.000.000,(11,4 miliar rupiah) pada perusahaan asuransi adalah pencucian uang berkedok polis asuransi dalam kasus dugaan suap yang melibatkan pejabat Direktorat Jenderal Bea dan Cukai dan PT. Tanjung Utama Jati. Pada kasus ini, staf bagian keuangan perusahaan PT. Tanjung Utama Jati mentransfer uang kepada seorang office boy yang kemudian ditransaksikan dalam bentuk polis asuransi atas nama pejabat Direktorat Jenderal Bea dan Cukai tersebut. (Ade Irma Junaidi dan Suryanto, www.antarnews.com)

PPATK (Pusat Pelaporan dan Analisa Transaksi Keuangan) mencatat transaksi mencurigakan dengan nilai relatif besar dan tidak sesuai profil dengan motif pembelian asuransi. Pola lain yang paling banyak digunakan adalah transaksi tunai baik dari setoran maupun tarikan tunai dan penempatan dana dalam bentuk investasi seperti kepemilikan deposito, ORI, obligasi, reksadana, saham, dan Sukuk. Hasil analisis PPATK mendapati lebih dari 2000 transaksi keuangan mencurigakan yang melibatkan pejabat dan staf pimpinan daerah diantaranya seorang Bupati yang membeli polis asuransi senilai Rp. 2.000.000.000,-. (Adi, http;//bandung.bisnis.com)

Untuk meredam merebaknya tindak pidana pencucian uang melalui lembaga keuangan, khususnya melalui perusahaan asuransi, maka penerapan Prinsip Kehatihatian dan Prinsip Mengenal Nasabah perlu untuk diperhatikan oleh setiap lembaga keuangan tersebut. Tanpa penerapan prinsip-prinsip ini dengn baik, maka tentunya tindak pidana pencucian uang tidak dapat diredam.

\section{PEMBAHASAN}

\section{a. Prinsip Mengenal Nasabah (Know Your Customer Principle)}

Prinsip mengenal nasabah (know your customer principle) tidak disebutkan dengan tegas dalam Undang-Undang Perbankan maupun dalam Peraturan Bank Indonesia Nomor 14/27/PBI/2012 tentang Penerapan Program Anti Pencucian Uang 
dan Pencegahan Pendanaan Terorisme Bagi Bank Umum. Prinsip ini baru dikenal sejak diterbitkannya Peraturan Bank Indonesia Nomor 3/10/PBI/2001 tentang Penerapan Prinsip Mengenal Nasabah (Know Your Customer Principles) sebagaimana terakhir diubah dengan Peraturan Bank Indonesia (PBI) Nomor 5/21/PBI/2003 tentang Perubahan Kedua Atas Peraturan Bank Indonesia Nomor 3/10/PBI/2001 tentang Penerapan Prinsip Mengenal Nasabah (Know Your Customer Principles). Dalam Pasal 1 angka 2 PBI ini dijelaskan bahwa "Prinsip Mengenal Nasabah adalah prinsip yang diterapkan Bank untuk mengetahui identitas nasabah, memantau kegiatan transaksi nasabah termasuk pelaporan transaksi yang mencurigakan".

Ketentuan-ketentuan yang dikeluarkan oleh Bank Indonesia dan Otoritas Jasa Keuangan ditujukan untuk meredam berbagai kejahatan yang dapat timbul dalam dunia perbankan dan lembaga keuangan lainnya, khususnya tindak pidana pencucian uang yang sangat rentan dapat dilakukan oleh nasabah. Prinsip Mengenal Nasabah (Know Your Customer Principles) adalah suatu prinsip yang mewajibkan bank untuk terlebih dahulu mengenali nasabahnya sebelum melakukan transaksi dengan nasabah yang bersangkutan. Prinsip mengenal nasabah tidak hanya berlaku bagi lembaga perbankan saja, tetapi juga berlaku bagi lembaga keuangan non bank. Untuk lembaga non bank, Kementerian Keuangan telah menerbitkan Keputusan Menteri Keuangan Nomor 45/KMK.06/2003 tentang Penerapan Prinsip Mengenal Nasabah Bagi Lembaga Keuangan Non Bank.

Tujuan dari Prinsip Mengenal Nasabah ini adalah agar lembaga keuangan, baik bank maupun non bank, mengetahui segala kegiatan nasabahnya yang berkaitan dengan transaksi yang dilakukan pada lembaga keuangan tersebut. Hal ini dilakukan untuk menjaga hubungan lembaga keuangan dengan nasabahnya agar dapat berjalan lancar dalam setiap transaksi yang dilakukan sehingga tidak menimbulkan kerugian bagi kedua belah pihak.

Pada Undang-Undang Pencucian Uang, Prinsip Mengenal Nasabah ini dikenal dengan istilah Prinsip Mengenali Pengguna Jasa yang terdiri atas Customer Due Delligence (CDD) dan Enhanced Due Delligence (EDD). CDD dan EDD dilakukan tidak hanya kepada calon nasabah tetapi juga kepada nasabah lama. Apabila dalam melakukan identifikasi terdapat transaksi yang mencurigakan dan tidak sesuai profil nasabah, maka Bank wajib menyampaikan Laporan Transaksi Keuangan Mencurigakan (LTKM) atau Laporan Transaksi Keuangan Tunai (LTKT) kepada pihak yang berwenang, yaitu Pusat Pelaporan dan Analisis Transaksi Keuangan (PPATK). CDD dilakukan dalam proses identifikasi, verifikasi, dan pemantauan nasabah. Hal ini untuk memastikan bahwa transaksi yang dilakukan telah sesuai dengan profil calon nasabah, sedangkan EDD digunakan pada saat melakukan hubungan usaha dengan nasabah mempunyai resiko yang lebih tinggi.

Pada Bulan Desember 1998, Basel Committee telah mengeluarkan kode etik perbankan yang salah satu isinya mewajibkan bank-bank untuk mengenali nasabahnya, yaitu melalui Prinsip Mengenal Nasabah. Basel Committe merekomendasikan Prinsip Mengenal Nasabah sebagai salah satu bentuk prudential regulation di lingkungan perbankan. Basel Committee berpendapat bahwa Prinsip Mengenal Nasabah memiliki relevansi yang khusus berkaitan dengan keselamatan dan kesehatan bank. Prinsip Mengenal Nasabah dapat melindungi reputasi dan integritas sistem perbankan karena dapat mengurangi risiko-risiko yang ditimbulkan dari transaksi perbankan yang dilakukan oleh bank itu sendiri. Walaupun rekomendasi dari Basel Committee bukan merupakan dokumen yang dapat dipaksakan berdasarkan hukum internasional, namun dengan kerja sama yang kuat antara organisasi internasional, maka penerapan Prinsip Mengenal Nasabah ini dapat dipatuhi oleh dunia internasional termasuk Indonesia. (Sutan Remy Sjahdeini, 2004; 224) 
Dalam menerapkan Prinsip Mengenal Nasabah, Bank wajib:

a. enetapkan kebijakan penerimaan Nasabah;

b. Menetapkan kebijakan dan prosedur dalam mengidentifikasi Nasabah;

c. Menetapkan kebijakan dan prosedur pemantauan terhadap rekening dan transaksi Nasabah;

d. Menetapkan kebijakan dan prosedur manajemen risiko yang berkaitan dengan penerapan Prinsip Mengenal Nasabah.

Kemudian dalam Pasal 3 Keputusan Menteri Keuangan RI Nomor 45/KMK.06/2003 tentang Penerapan Prinsip Mengenal Nasabah Bagi Lembaga Keuangan Non Bank dijelaskan bahwa

Dalam rangka menerapkan Prinsip Mengenal Nasabah sebagaimana dimaksud dalam Pasal 2, LKNB wajib:

a. Menetapkan kebijakan penerimaan nasabah;

b. Menetapkan kebijakan dan prosedur dalam mengidentifikasi Nasabah;

c. Menetapkan kebijakan dan prosedur pemantauan terhadap rekening dan transaksi Nasabah; dan

d. Menetapkan kebijakan dan prosedur manajemen risiko yang berkaitan dengan penerapan Prinsip Mengenal Nasabah.

\section{b. Penerapan Prinsip Mengenal Nasabah (Know Your Customer) Pada Perusahaan} Asuransi

Terkhusus mengenai penerapan prinsip mengenal nasabah pada lembaga keuangan non bank, Menteri Keuangan RI telah menerbitkan Peraturan Menteri Keuangan Nomor 74/PMK.012/2006 tentang Penerapan Prinsip Mengenal Nasabah Bagi Lembaga Keuangan Non Bank yang pada perkembangannya kemudian diurevisi dan diubah dengan Peraturan Menteri Keuangan Nomor 30/PMK.010/2010 tentang Penerapan Prinsip Mengenal Nasabah Bagi Lembaga Keuangan Non Bank. Peraturan ini diterbitkan dengan pertimbangan semakin kompleksnya produk, aktivitas, dan teknologi informasi di lingkungan industri perasuransian, dana pensiun dan lembaga pembiayaan, maka risiko pemanfaatan asuransi, dana pensiun, dan lembaga pembiayaan digunakan sebagai sarana pencucian uang dan pendanaan teroris semakin terbuka. Atas dasar pertimbangan ini, maka PMK Nomor 74/PMK.012/2006 kemudian direvisi dan diubah menjadi PMK Nomor 30/PMK.010/2010 untuk disesuaikan dengan perkembangan zaman.

Lembaga Keuangan Non Bank (LKNB) yang dimaksud dalam PMK Nomor 30/PMK.010/2010 ini adalah Perusahaan Perasuransian, Dana Pensiun, dan Lembaga Pembiayaan. Kemudian Prinsip Mengenal Nasabah adalah prinsip yang diterapkan LKNB untuk mengetahui latar belakang dan identitas Nasabah, memantau Rekening dan transaksi Nasabah, serta melaporkan Transaksi Keuangan Mencurigakan dan Transaksi Keuangan yang Dilakukan Secara Tunai, termasuk transaksi keuangan yang terkait dengan Pendanaan Kegiatan Terorisme. Sedangkan nasabah yang dimaksudkan adalah pihak yang menggunakan jasa LKNB, termasuk tetapi tidak terbatas pada:

1. pemegang polis dan/atau tertanggung pada perusahaan asuransi kerugian dan perusahaan asuransi jiwa;

2. klien pada perusahaan pialang asuransi;

3. peserta dan/atau pihak yang berhak atas manfaat pensiun pada Dana Pensiun;

4. klien atau penjual piutang pada kegiatan anjak piutang;

5. konsumen pada kegiatan pembiayaan konsumen;

6. lessee atau penyewa guna usaha pada kegiatan leasing atau sewa guna usaha;

7. pemegang kartu kredit pada usaha kartu kredit;

8. perusahaan pasangan usaha pada kegiatan modal ventura; dan

9. debitur pada perusahaan pembiayaan infrastruktur. 
PMK Nomor 30/PMK.010/2010 ini mewajibkan kepada LKNB untuk menerapkan Prinsip Mengenal Nasabah sebagaimana diatur dalam Pasal 2. Dalam menerapkan Prinsip Mengenal Nasabah ini, LKNB wajib:

1. menetapkan kebijakan dan prosedur penerimaan Nasabah;

2. menetapkan kebijakan dan prosedur dalam mengidentifikasi Nasabah;

3. menetapkan kebijakan dan prosedur pemantauan Rekening dan pelaksanaan transaksi Nasabah; dan

4. menetapkan kebijakan dan prosedur manajemen risiko yang berkaitan dengan penerapan Prinsip Mengenal Nasabah.

Untuk pelaksanaan prinsip ini, maka LKNB wajib:

1. membentuk unit kerja khusus atau menugaskan anggota direksi atau pengurus atau pejabat setingkat di bawah direksi atau pengurus yang bertanggung jawab menangani penerapan Prinsip Mengenal Nasabah.

2. menetapkan kebijakan dan prosedur tertulis tentang penerimaan Nasabah, identifikasi dan verifikasi Nasabah, pemantauan terhadap Rekening dan transaksi Nasabah, dan manajemen risiko yang berkaitan dengan penerapan Prinsip Mengenal Nasabah, yang dituangkan dalam pedoman pelaksanaan penerapan Prinsip Mengenal Nasabah.

3. menyampaikan pedoman pelaksanaan penerapan Prinsip Mengenal Nasabah sebagaimana dimaksud pada huruf b kepada Menteri Keuangan c.q. Ketua Badan Pengawas Pasar Modal dan Lembaga Keuangan.

4. menyampaikan setiap perubahan atas pedoman pelaksanaan penerapan Prinsip Mengenal Nasabah sebagaimana dimaksud pada huruf $b$ kepada Menteri Keuangan c.q. Ketua Badan Pengawas Pasar Modal dan Lembaga Keuangan paling lama 7 (tujuh) hari kerja sejak ditetapkannya perubahan tersebut.

Ketentuan mengenai pedoman pelaksanaan penerapan Prinsip Mengenal Nasabah sebagaimana angka 2 di atas diatur lebih lanjut dengan Peraturan Ketua Badan Pengawas Pasar Modal dan Lembaga Keuangan. Peraturan Ketua Badan Pengawas Pasar Modal dan Lembaga Keuangan yang dimaksud diterbitkan pada Tahun 2011, yakni Peraturan Ketua Badan Pengawas Pasar Modal dan Lembaga Keuangan Nomor PER-05/BL/2011 tentang Pedoan Pelaksanaan Prinsip Mengenal Nasabah Bagi Perusahaan Pembiayaan.

Selanjutnya diatur dalam Pasal 5 PMK Nomor 30/PMK.010/2010 ini bahwa LKNB wajib memastikan bahwa unit kerja khusus dan/atau anggota direksi atau pengurus atau pejabat setingkat di bawah direksi atau pengurus LKNB yang bertanggung jawab atas penerapan Prinsip Mengenal Nasabah memiliki kemampuan dan kewenangan untuk mengakses seluruh data Nasabah dan informasi lainnya yang terkait. Pihak yang mengajukan permohonan untuk mendapatkan izin usaha bagi Perusahaan Perasuransian dan Lembaga Pembiayaan atau pengesahan peraturan Dana Pensiun untuk pertama kali bagi Dana Pensiun, wajib menyampaikan pedoman pelaksanaan penerapan Prinsip Mengenal Nasabah bersama dengan permohonannya.

Untuk optimalisasi penerapan Prinsip Mengenal Nasabah, maka sebelum melakukan Perikatan dengan Nasabah, LKNB wajib meminta informasi mengenai:

1. latar belakang dan identitas calon Nasabah;

2. maksud dan tujuan calon Nasabah melakukan Perikatan;

3. profil keuangan calon Nasabah;

4. informasi lain yang memungkinkan LKNB untuk dapat mengetahui profil calon Nasabah termasuk Perikatan yang telah dimiliki sebelumnya dengan LKNB yang bersangkutan; dan

5. identitas penerima kuasa yang bertindak untuk dan atas nama calon Nasabah. Informasi tersebut di atas harus dapat dibuktikan dengan keberadaan dokumen-dokumen pendukung sebagai berikut: 
1. calon Nasabah perorangan paling kurang terdiri dari:

a. dentitas Nasabah yang memuat nama, alamat atau tempat tinggal sesuai KTP/SIM/Paspor dan nomor telepon, alamat tempat tinggal terkini dan nomor telepon (jika ada), tempat dan tanggal lahir, dan kewarganegaraan.

b. keterangan mengenai pekerjaan;

c. spesimen tanda tangan; dan

d. keterangan mengenai sumber dana dan tujuan penggunaan dana;

e. rata-rata penghasilan;

f. nama dan nomor rekening bank calon Nasabah, jika ada; dan

g. dokumen-dokumen lain yang memungkinkan LKNB untuk dapat mengetahui profil calon Nasabah;

2. calon Nasabah yang berbentuk perusahaan paling kurang terdiri dari:

a. dokumen mengenai perusahaan:

1) keterangan mengenai nama, alamat, dan nomor telepon perusahaan;

2) akte pendirian atau anggaran dasar bagi perusahaan yang bentuknya diatur dalam peraturan perundang- undangan yang berlaku berikut perubahan anggaran dasar yang terakhir;

3) izin usaha atau izin lainnya dari instansi yang berwenang;

4) surat keterangan domisili;

5) laporan keuangan terkini; dan

6) Nomor Pokok Wajib Pajak (NPWP);

b. nama, spesimen tanda tangan dan kuasa kepada pihak- pihak yang ditunjuk mempunyai wewenang bertindak untuk dan atas nama perusahaan dalam melakukan hubungan usaha dengan LKNB;

c. dokumen identitas pihak-pihak yang ditunjuk mempunyai wewenang bertindak untuk dan atas nama perusahaan;

d. keterangan mengenai sumber dana dan tujuan penggunaan dana, bagi calon Nasabah pada Lembaga Pembiayaan dan Perusahaan Perasuransian; dan

e. dokumen-dokumen lain yang memungkinkan LKNB untuk dapat mengetahui profil calon Nasabah.

Selanjutnya LKNB wajib melakukan identifikasi dan verifikasi atas dokumen pendukung (customer due diligence) dengan melakukan hal-hal antara lain:

1. meneliti kemungkinan adanya hal-hal yang tidak wajar atau mencurigakan.

2. memastikan kebenaran dokumen calon Nasabah, dalam hal terdapat kecurigaan atas dokumen yang diterima, antara lain dengan cara:

a. melakukan wawancara dengan calon Nasabah;

b. meminta dokumen lain yang dikeluarkan oleh pihak yang berwenang;

c. melakukan pemeriksaan silang dari berbagai informasi yang disampaikan oleh calon Nasabah.

3. melakukan penelaahan mengenai Beneficial Owner.

Pelaku pencucian uang senantiasa terus mencari setiap peluang agar harta kekayaan hasil kejahatannya dapat dicuci sehingga nampak seolah-olah merupakan hasil kegiatan yang sah. Dalam hal bank umum dianggap kurang aman, tidak menutup kemungkinan pencuci uang akan memanfaatkan produk BPR. Demikian pula dalam hal produk perbankan konvensional dianggap kurang aman, maka pencuci uang dapat mengalihkannya pada produk perbankan dengan prinsip syariah. Dengan kata lain, tidak ada satu produk pun baik di bank umum maupun BPR yang luput dari incaran pelaku pencuci uang. Kondisi yang demikian juga terjadi pada lembaga keuangan non bank lainnya seperti lembaga asuransi.

Aktifitas pencucian uang secara umum merupakan suatu cara menyembunyikan atau menyamarkan asal usul harta kekayaan yang diperoleh dari hasil tindak pidana sehingga nampak seolah-olah harta kekayaan dari hasil tindak pidana tersebut sebagai hasil kegiatan yang sah. Lebih rinci di dalam Pasal 1 angka 1 
Undang-Undang Nomor 25 Tahun 2003 tentang Perubahan Atas Undang-Undang Nomor 15 Tahun 2002 tentang Tindak Pidana Pencucian Uang dan terakhir diubah dengan Undang-Undang Nomor 8 Tahun 2010 tentang Pencegahan dan Pemberantasan Tindak Pidana Pencucian Uang (UU TPPU), pencucian uang didefinisikan sebagai perbuatan menempatkan, mentransfer, membayarkan, membelanjakan, menghibahkan, menyumbangkan, menitipkan, membawa ke luar negeri, menukarkan, atau perbuatan lainnya atas Harta Kekayaan yang diketahui atau patut diduga merupakan hasil tindak pidana dengan maksud untuk menyembunyikan atau menyamarkan asal usul Harta Kekayaan sehingga seolah-olah menjadi harta kekayaan yang sah. UU TPPU telah membatasi bahwa hanya harta kekayaan yang diperoleh dari 24 jenis tindak pidana dan tindak pidana lainnya yang diancam dengan hukuman 4 tahun penjara atau lebih sebagaimana disebutkan dalam Pasal 2 UU TPPU yang dapat dijerat dengan sanksi pidana pencucian uang sebagaimana diatur dalam Pasal 3 dan Pasal 6 UU TPPU.

Modus kejahatan pencucian uang waktu ke waktu semakin kompleks dengan menggunakan tehnologi dan rekayasa keuangan. Sekalipun terdapat berbagai macam modus operandi pencucian uang, namun pada dasarnya proses pencucian uang dapat dikelompokkan ke dalam tiga tahap kegiatan, yaitu:

a. Placement adalah upaya menempatkan dana yang dihasilkan dari suatu kegiatan tindak pidana ke dalam sistem keuangan. Bentuk kegiatan ini antara lain:

1) Menempatkan dana pada bank. Kadang-kadang kegiatan ini diikuti dengan pengajuan kredit/pembiayaan.

2) Menyetorkan uang pada PJK sebagai pembayaran kredit untuk mengaburkan audit trail.

3) Menyelundupkan uang tunai dari suatu negara ke negara lain.

4) Membiayai suatu usaha yang seolah-olah sah atau terkait dengan usaha yang sah berupa kredit/pembiayaan, sehingga mengubah kas menjadi kredit/pembiayaan.

5) Membeli barang-barang berharga yang bernilai tinggi untuk keperluan pribadi, membelikan hadiah yang nilainya mahal sebagai penghargaan/hadiah kepada pihak lain yang pembayarannya dilakukan melalui PJK.

b. Layering adalah memisahkan hasil tindak pidana dari sumbernya yaitu tindak pidananya melalui beberapa tahap transaksi keuangan untuk menyembunyikan atau menyamarkan asal-usul dana. Dalam kegiatan ini terdapat proses pemindahan dana dari beberapa rekening atau lokasi tertentu sebagai hasil placement ke tempat lain melalui serangkaian transaksi yang kompleks dan didesain untuk menyamarkan dan menghilangkan jejak sumber dana tersebut. Bentuk kegiatan ini antara lain sebagai berikut:

1) Transfer dana dari satu bank ke bank lain dan atau antar wilayah/negara.

2) Penggunaan simpanan tunai sebagai agunan untuk mendukung transaksi yang sah.

3) Memindahkan uang tunai lintas batas negara melalui jaringan kegiatan usaha yang sah maupun shell company.

c. Integration adalah upaya menggunakan harta kekayaan yang telah tampak sah, baik untuk dinikmati langsung, diinvestasikan ke dalam berbagai bentuk kekayaan material maupun keuangan, dipergunakan untuk membiayai kegiatan bisnis yang sah, ataupun untuk membiayai kembali kegiatan tindak pidana.

Dalam melakukan pencucian uang, pelaku tidak terlalu mempertimbangkan hasil yang akan diperoleh, dan besarnya biaya yang harus dikeluarkan karena tujuan utamanya adalah untuk menyamarkan atau menghilangkan asal-usul uang sehingga hasil akhirnya dapat dinikmati atau digunakan secara aman. Ketiga kegiatan tersebut di atas dapat terjadi secara terpisah atau simultan, namun umumnya dilakukan secara tumpang tindih. 
Ketiga tahapan pencucian uang tersebut di atas pada dasarnya dilakukan untuk memisahkan atau menjauhkan antara uang atau harta hasil kejahatan dengan si pelaku sehingga proses hukum konvensional akan mengalami kesulitan dalam melacak si pelaku. Sebagaimana diketahui harta kekayaan dari hasil pencucian uang merupakan titik terlemah dari kegiatan pencucian uang itu sendiri. Apabila hasil kegiatan pencucian uang dapat ditelusuri, maka akan secara mudah diidentifikasi pihak-pihak yang melakukannya dan pada akhirnya teridentifikasi kegiatannya. Atas dasar hal ini, maka dibuatlah suatu mekanisme anti pencucian uang yang diiplementasikan salah satunya dengan prinsip mengenal nasabah.

Proses pendeteksian kegiatan pencucian uang, baik pada tahap placement, layering maupun integration akan menjadi dasar untuk merekonstruksi hubungan antara uang atau harta hasil kejahatan dengan si pelaku. Apabila telah terdeteksi dengan baik, proses hukum dapat segera dimulai, baik dalam rangka mendakwa tindak pidana pencucian uang maupun kejahatan asal yang dilakukan oleh si pelaku. Inilah yang menjadi alasan utama mengapa perusahaan jasa keuangan diwajibkan melaporkan transaksi keuangan mencurigakan dan transaksi keuangan tunai yang tidak wajar yang dilakukan oleh nasabahnya.

Setiap Perusahaan Jasa Keuangan (PJK) atau Lembaga Keuangan (LK), khususnya Lembaga Keuangan Non Bank (LKNB), harus terus menerus mewaspadai para kriminal yang memanfaatkan sistem keuangan sebagai sarana kegiatan pencucian uang. Tugas mendeteksi tindak pidananya terutama dilakukan oleh penegak hukum, PJK pada saat tertentu, atau karena tuntutan proses hukum membantu penegak hukum untuk melaksanakan tugasnya. Oleh karena itu, kewaspadaan sangat diperlukan untuk menghindari pemanfaatan sistem keuangan sebagai sarana pencucian uang dan juga melakukan tindakan yang diperlukan untuk menanggulanginya. Kewajiban untuk waspada pada pokoknya terdiri dari lima unsur yaitu:

1. Identifikasi dan verifikasi nasabah/pengguna jasa keuangan;

2. Identifikasi transaksi keuangan mencurigakan (suspicious transactions) dan transaksi tunai dalam jumlah tertentu (cash transactions);

3. Pelaporan transaksi keuangan;

4. Menatausahakan dokumen;

5. Pelatihan karyawan.

Kewaspadaan dapat dilakukan apabila setiap PJK memiliki sistem yang memungkinkan dilaksanakannya beberapa hal sebagai berikut:

a. Mengetahui identitas sebenarnya dari nasabah yang menggunakan jasanya;

b. Mengidentifikasi transaksi keuangan mencurigakan dan melaporkannya kepada PPATK;

c. Mengidentifikasi transaksi tunai dalam jumlah tertentu dan melaporkannya kepada PPATK;

d. Menyimpan dokumen/data selama waktu yang ditentukan;

e. Memberikanpelatihankepadapejabatdanstafterkait;

f. Berkoordinasi secara erat dengan PPATK untuk hal-hal yang terkait dengan sistem dan kebijakan untuk waspada;

g. Memastikan bahwa internal audit dan unit kerja compliance/kepatuhan melakukan pemantauan terhadap pelaksanaan dan operasional sistem dan kebijakan intern masing- masing PJK.

Karena PJK mencakup bermacam-macam jenis organisasi, dalam skala besar maupun kecil, maka sifat dan cakupan sistem kewaspadaan yang tepat untuk setiap institusi atau organisasi dapat bervariasi tergantung pada ukuran, struktur dan sifat dasar dari kegiatan usahanya. Namun demikian terlepas dari ukuran dan strukturnya, setiap PJK wajib melaksanakan standar kewaspadaan sebagaimana yang telah diuraikan di atas. Sistem kewaspadaan harus dapat membuat 
petugas/staf yang berwenang untuk bereaksi secara cepat dan tepat terhadap kejadian dan keadaan yang mencurigakan dengan cara melaporkannya kepada pejabat yang bertanggung jawab. Oleh karena itu, perlu dilakukan pelatihan terhadap karyawan secara terus menerus. Pada setiap PJK harus terdapat pejabat/petugas sebagai contact person dengan PPATK untuk penanganan kasus-kasus nasabah dan transaksi keuangan yang dilaporkan. Hal ini akan mempercepat dan mempermudah penanganan selanjutnya baik oleh PPATK maupun oleh aparat penegak hukum.

Sebagaimana telah dijelaskan sebelumnya bahwa untuk optmalisasi penerapan prinsip mengenal nasabah pada lembaga keuangan non bank, maka diterbitkan PMK Nomor 74/PMK.012/2006 yang kemudian direvisi dan diubah menjadi PMK Nomor 30/PMK.010/2010. Untuk memperkuat ketentuan yang ada, maka Otoritas Jasa Keuangan (OJK) kemudian menerbitkan pula Peraturan OJK Nomor Nomor 12 /POJK.01/2017 tentang Penerapan Program Anti Pencucian Uang dan Pencegahan Pendanaan Terorisme Di Sektor Jasa Keuangan. Peraturan OJK Nomor 12/POJK.01/2017 ini diterbitkan dengan pertimbangan bahwa:

a. bahwa dengan semakin berkembangnya kompleksitas produk dan layanan jasa keuangan termasuk pemasarannya (multi channel marketing), serta semakin meningkatnya penggunaan teknologi informasi pada industri jasa keuangan, maka semakin tinggi risiko Penyedia Jasa Keuangan digunakan sebagai sarana Pencucian Uang dan/atau Pendanaan Terorisme;

b. bahwa peningkatan risiko yang dihadapi Penyedia Jasa Keuangan perlu diimbangi dengan peningkatan kualitas penerapan program anti Pencucian Uang dan/atau pencegahan Pendanaan Terorisme yang didasarkan pada pendekatan berbasis risiko (risk based approach) sesuai dengan prinsip-prinsip umum yang berlaku secara internasional;

c. bahwa perlu adanya harmonisasi dan integrasi pengaturan mengenai penerapan program anti Pencucian Uang dan/atau pencegahan Pendanaan Terorisme di sektor jasa keuangan;

Penerapan prinsip mengenal nasabah pada perusahaan asuransi lebih spesifik lagi diatur dalam Peraturan Ketua Badan Pengawas Pasar Modal dan Lembaga Keuangan (Bapepam dan LK) Nomor Per-01/BL 2011 tentang Pedoman Pelaksanaan Prinsip Mengenal Nasabah Bagi Perusahaan Perasuransian. Ketentuan ini merupakan turunan dari PMK Nomor 30/PMK.010/2010, yakni sebagai ketentuan pelaksanaan Pasal 4 ayat (5) PMK Nomor 30/PMK.010/2010. Pasal 1 ayat (1) Peraturan Ketua Bapepam dan LK Nomor Per-01/BL 2011 tersebut mewajibkan kepada Perusahaan Perasuransian untuk menyusun pedoman pelaksanaan prinsip mengenal nasabah sesuai dengan petunjuk penyusunan yang tercantum dalam lampiran Peraturan Ketua Bapepam dan LK Nomor Per-01/BL 2011 tersebut. Atas dasar perintah Peraturan Ketua Bapepam dan LK Nomor Per-01/BL 2011 ini, maka setiap perusahaan perasuransian yang beroperasi di Indonesia haruslah memiliki pedoman pelaksanaan prinsip mengenal nasabah yang diimplementasikan oleh perusahaan perasuransian dalam bentuk pedoman dan SOP. Pedoman dan SOP tersebut menjadi acuan bagi perusahaan untuk mencari dan menyeleksi calon nasabahnya sehingga dapat mengantisipasi kegiatan pencucian uang. Hal yang sama juga dilakukan oleh PT. Prudential Life Assurance (Prudential Indonesia) yang dalam mencari dan menyeleksi calon nasabahnya berpedoman pada Pedoman dan Standar Operasional Prosedur (SOP) Pelaksanaan Penerapan Prinsip Mengenal Nasabah.

Dalam lampiran Peraturan Ketua Bapepam dan LK Nomor Per-01/BL 2011 mengenai Petunjuk Penyusunan Pedoman Pelaksanaan Penerapan Prinsip Mengenal Nasabah Bagi Perusahaan Perasuransian dijelaskan bahwa penyusunan Pedoman Pelaksanaan Penerapan Prinsip Mengenal Nasabah (P4MN) bagi perusahaan perasuransian disesuaikan dengan keadaan, struktur organisasi, dan jenis usaha masing-masing perusahaan perasuransian. Tujuan penyusunan P4MN adalah agar 
setiap perusahaan perasuransian dapat mengenali profil nasabahnya sehingga pada gilirannya perusahaan perasuransian dapat mengidentifikasi adanya transaksi nasabah yang dapat dikategorikan menjadi transaksi keuangan yang tidak wajar dan transaksi keuangan yang dilakukan secara tunai. Berdasarkan hasil identifikasi tersebut, perusahaan perasuransian menyampaikan laporan transaksi keuangan mencurigakan dan/atau laporan transaksi keuangan tunai kepada Pusat Pelaporan dan Analisis Transaksi Keuangan (PPATK).

P4MN perusahaan perasuransian wajib menjabarkan paling kurang hal-hal sebagai berikut:

1. Penanggung Jawab Penerapan Prinsip Mengenal Nasabah;

2. Kebijakan dan prosedur penerimaan nasabah;

3. Kebijakan dan prosedur dalam mengidentifikasi dan memverifikasi nasabah;

4. Kebijakan dan prosedur pemantauan rekening dan pelaksanaan transaksi nasabah;

5. Kebijakan dan prosedur menejemen resiko yang berkaitan dengan penerapan Prinsip Mengenal Nasabah (PMN).

Hampir semua perusahaan asuransi di Indonesia memiliki Pedoman dan SOP Pelaksanaan Penerapan Prinsip Mengenal Nasabah dengan model yang sama oleh sebab sistematikanya sudah ditentukan dalam Peraturan Ketua Bapepam dan LK Nomor Per-01/BL 2011. Begitu pula di Kota Makassar, perusahaan perasuransian yang beraktivitas di Kota Makassar pada dasarnya merupakan perusahaan perasuransian yang merupakan cabang dimana kantor pusatnya berada di ibukota negara, yakni DKI Jakarta. Pedoman dan SOP yang digunakan oleh perusahaan perasuransian tersebut adalah pedoman dan SOP yang sama antara kantor pusat dengan kantor cabangnya yang beroperasi di seluruh wilayah Negara Indonesia.

Di Kota Makassar misalnya, Pedoman dan SOP yang digunakan oleh semua perusahaan asuransi di Kota Makassar sama dengan Pedoman dan SOP yang diterbitkan oleh kantor pusat perusahaan asuransi tersebut. Di PT. (Persero) Asuransi Kredit Indonesia dan PT. Prudential Life Assurance (Prudential Indonesia) misalnya, Pedoman dan SOP yang digunakannya adalah Pedoman dan SOP yang diterbitkan oleh Kantor Pusatnya. Tiap perusahaan asuransi menggunakan istilah yang berbedabeda, ada yang menggunkana istilah Pedoman dan SOP, Pedoman Prinsip Mengenal Nasabah, ataupun Standar Operasional Prosedur Prinsip Mengenal Nasabah. Walaupun berbeda-beda, pada prinsipnya isi dari pedoman dan SOP tersebut adalah sama karena berpedoman pada Peraturan Ketua Bapepam dan LK Nomor Per-01/BL 2011. Adapun sistematika Pedoman dan SOP Prinsip Mengenal Nasabah yang penulis dapatkan pada PT. (Persero) Asuransi Kredit Indonesia adalah sebagai berikut:

Bab I Pendahuluan, berisi:

a. Latar Belakang

b. Maksud dan Tujuan

c. Pengertian Umum.

Bab II Penanggung Jawab Pelaksanaan Penerapan Prinsip Mengenal Nasabah (Manajemen), berisi:

a. Ketentuan Umum

b. Penugasan Penanggung Jawab P4MN

c. Tugas, Wewenang, dan Tanggung Jawab Penanggung Jawab P4MN di Kantor Pusat

d. Tugas, Wewenang, dan Tanggung Jawab Penanggung Jawab P4MN di Kantor Cabang dan Kantor Unit Pelayanan

Bab III Kebijakan dan Prosedur, berisi:

a. Kebijakan dan Prosedur Penerimaan Nasabah

b. Kebijakan dan Prosedur Identifikasi dan Verifikasi Nasabah dan/atau Beneficial Owner (BO) 
c. Kebijakan dan Prosedur Pemantauan Rekening dan Pelaksanaan Transaksi Nasabah

d. Kebijakan dan Prosedur Manajemen Risiko yang Berkaitan Dengan Penerapan Prinsip Mengenal Nasabah

e. Sanksi Terhadap Pelanggaran Ketentuan Terkait Penerapan Prinsip Mengenal Nasabah

Bab IV Penutup

Jika melihat Pedoman dan SOP tersebut di atas, dapat ditegaskan bahwa perusahaan asuransi yang beroperasi di Indonesia betul-betul mewaspadai adanya kegiatan pencucian uang di Indonesia. Untuk mengetahui nasabahnya, maka perusahaan asuransi dalam penerimaan nasabah baru menggunakan formulir aplikasi yang telah tersedia. Persetujuan penerimaan nasabah hanya dapat dilakukan setelah perusahaan dapat meyakini kebenaran identitas dan kelengkapan dokumen calon nasabah serta mempertimbangkan faktor-faktor yang dapat memungkinkan calon nasabah melakukan kegiatan pencucian uang dan/atau pendanaan kegiatan terorisme. Selanjutnya mengenai prosedur identifikasi dan verifikasi nasabah atau Beneficial Owner (BO) adalah sebagai berikut:

1. Kebijakan Identifikasi dan Verifikasi calon Nasabah atau BO.

Kriteria untuk menerapkan CDD secara lebih sederhana, standar, dan lebih ketat antara lain:

a. Karakteristik/jenis asuransi yang dipasarkan, jumlah premi yang dibayarkan, nilai dan objek pertanggungan, pola transaksi yang dilakukan, profil nasabah, profil bisnis nasabah, negara asal nasabah.

b. Pertimbangan dalam menentukan kriteria penerapan CDD yaitu :

1) CDD lebih sederhana

- Tidak menjanjikan pengembalian dana sebelum dan setelah berakhirnya masa pertanggungan;

- Produk asuransi yang jumlah pembayaran premi regulernya dalam setahun tidak melebihi Rp 25.000.000 (dua puluh lima juta rupiah);

- Produk asuransi yang pembayaran premi tunggalnya tidak melebihi Rp 25.000.000 (dua puluh lima juta rupiah).

2) CDD standar

- Pembatalan penutupan karena adanya keberatan nasabah untuk memberikan informasi yang lengkap;

- Penutupan asuransi yang mempertanggungkan barang dalam perjalanan dengan nilai pertanggungan yang tidak sesuai dengan nilai barang yang sebenarnya.

3) CDD lebih ketat

Enhanced Due Diligence (EDD) dilakukan apabila tingkat risiko terjadinya pencucian uang atau pendanaan terorisme dianggap/ diklasifikasikan tinggi. Tingginya tingkat risiko dapat dilihat dari :

- Latar belakang atau profil calon nasabah yang berisiko tinggi;

- Bidang usaha yang memiliki risiko tinggi;

- Negara atau domisili nasabah yang memiliki risiko tinggi;

- Calon nasabah yang tercantum dalam daftar nama-nama teroris.

c. Melakukan pengujian latar belakang dan tujuan dari TKM, TKT, Transaksi yang tidak wajar, atau transfer dana dari dan ke luar negeri;

d. Pejabat/pegawai bertanggungjawab dalam melakukan identifikasi transaksi calon nasabah atau BO;

e. Dalam hal teridentifikasi dan dinyatakan memiliki tingkat risiko tinggi serta memenuhi kriteria untuk dilakukan penolakan harus memperoleh persetujuan direksi. 
2. Prosedur Identifikasi dan Verifikasi Calon Nasabah

a. CDD lebih sederhana

Meminta informasi calon nasabah dan mencocokkan dokumen pendukung tersebut dengan dokumen yang diberikan untuk memastikan keabsahannya.

b. CDD standar

1) Melakukan kegiatan sbagaimana CDD lebih sederhana;

2) Meneliti hal-hal yang tidak wajar atau mencurigakan;

3) Memastikan kebenaran dokumen calon nasabah;

4) Melakukan penelaahan mengenai BO.

c. CDD lebih ketat

1) Melakukan kegiatan sbagaimana CDD standar;

2) Melakukan verifikasi terhadap informasi calon nasabah atau BO;

3) Melakukan verifikasi hubungan bisnis yang dilakukan oleh calon nasabah atau BO dengan pihak ketiga/pihak lain;

4) Melakukan CDD secara berkala (meliputi analisa informasi mengenai calon nasabah, sumber dana, tujuan transaksi, dan hubungan usaha dengan pihak terkait).

Dalam lampiran Keputusan Kepala Pusat Pelaporan dan Analisis Transaksi Keuangan Nomor 21/1/Kep.PPATK/2003 tentang Pedoman Umum Pencegahan dan Pemberantasan Tindak Pidana Pencucian Uang Bagi Penyedian Jasa Keuangan dijelaskan bahwa terdapat beberapa ukuran yang harus diperhatikan dalam mengidentifikasi transaksi-transaksi nasabah yang harus dipandang sebagai transaksi keuangan mencurigakan, yakni sebagai berikut:

1. Setoran tunai yang cukup besar dalam satu transaksi atau kumpulan dari transaksi, khususnya apabila:

a. Transaksi dari kegiatan usaha yang biasa dilakukan oleh nasabah tidak tunai tetapi dalam bentuk lain seperti cek, bank draft, letter of credit, bills ofexchange atau instrumen lain.

b. Setoran ke dalam suatu rekening semata-mata agar nasabah dapat melakukan transaksi bank draft, transfer atau instrumen pasar uang yang dapat diperjualbelikan.

2. Nasabah atau kuasanya berupaya menghindari untuk berhubungan secara langsung dengan PJK.

3. Penggunaan nominee accounts, trustee accounts dan client accounts yang sebenarnya tidak perlu dilakukan dan tidak konsisten dengan kegiatan usaha nasabah.

4. Penggunaan banyak rekening dengan alasan yang tidak jelas.

5. Penyetoran dalam nominal kecil dengan frekuensi yang cukup tinggi, dan kemudian dilakukan penarikan secara sekaligus.

6. Sering melakukan pemindahan dana antar rekening pada negara/wilayah yang berbeda.

7. Adanya jumlah yang hampir sama antara dana yang ditarik dengan yang disetor secara tunai pada hari yang sama atau hari sebelumnya.

8. Penarikan dalam jumlah besar terhadap rekening yang tidak aktif.

9. Penarikan dalam jumlah besar terhadap rekening yang baru menerima dana yang tidak diduga dan tidak biasa dari luar negeri.

10. Nasabah yang memperlihatkan kehati-hatian yang berlebihan terutama terhadap kerahasiaan identitas atau kegiatan usahanya, atau nasabah yang menundanunda untuk memberikan informasi dan dokumen pendukung mengenai identitasnya.

11. Nasabah yang berasal dari atau yang mempunyai rekening di negara yang dikenal sebagai tempat pencucian uang atau negara yang kerahasiaan banknya sangat ketat. 
12. Adanya transfer dana ke dalam suatu rekening dengan frekuensi yang sangat tinggi dan secara tiba-tiba padahal sebelumnya rekening tersebut tergolong tidak aktif.

13. Pembayaran atas pembelian saham yang dilakukan melalui transfer dari rekening atas nama pihak lain.

Secara yuridis, ketentuan mengenai penerapan prinsip mengenal nasabah dalam upaya mencegah kegiatan pencucian uang pada bank dan lembaga keuangan non bank sudah cukup komprehensif. Selanjutnya kembali kepada perusahaan jasa keuangan yang bersangkutan bagaimana ia melaksanakan sengan baik perintah peraturan perundang-undangan sehingga kegiatan pencucian uang dapat dicegah. Untuk itu, maka setiap perusahaan jasa keuangan, baik bank dan non bank dituntut untuk melaksanakan setiap tahapan-tahapan dalam mengenali nasabah-nasabahnya dan terkhusus memantau transaksi-transaksi keuangan nasabahnya.

\section{c. Bentuk Perlindungan Hukum Bagi Perusahaan Asuransi Pada Kegiatan Pencucian Uang}

Pentingnya pencegahan dan pemberantasan pencucian uang pada lembaga perbankan dan penyedia jasa keuangan non bank karena dampaknya tidak hanya merugikan keuangan negara, tetapi juga memberikan dampak bagi stabilitas nasional. Secara umum ada beberapa alasan mengapa pencucian uang (money laundering) diperangi dan dinyatakan sebagai tindak pidana, yaitu:

1. Pengaruh money laundering pada sistem keuangan ekonomi diyakini berdampak negatif bagi perekonomian dunia. Fluktuasi yang tajam pada nilai tukar dan suku bunga merupakan bagian dari akibaat negatif dari pencucian uang. Dengan adanya berbagai dampak negatif itu diyakini, bahwa money laundering dapat mempengaruhi perekonomian dunia;

2. Dengan dinyatakan money laundering sebagai tindak pidana akan lebih memudahkan bagi aparat penegak hukum untuk menyita hasil tindak pidana yang kadangkala sulit disita, misalnya, asset yang susah dilacak atau dipindahtangankan kepada pihat ketiga, dengan ini maka pemberantasan tindak pidana sudah berailh orientasinya dari "menindak pelakunya" kearah menyita "hasil tindak pidana";

3. Dengan dinyatakan money laundering sebagai tindak pidana dan dengan adanya sistem pelaporan transaksi dalam jumlah tertentu dan traksaksi yang mencurigakan, maka hal ini lebih memudahkan bagi para penegak hukum untuk menyelidiki kasus pidana sampai kepada tokoh-tokoh yang ada dibelakangnya. (Yunus Husein, 2007; 262)

Penerapan prinsip mengenal nasabah merupakan upaya untuk mencegah dan memberantas kegiatan pencucian uang yang dilakukan oleh pihak-pihak yang tidak bertanggung jawab atas harta kekayaan yang didapatkannya dari hasil tindak pidana. Harta kekayaan yang dimaksud dapat dilihat pada ketentuan Pasal 2 Undang-Undang Tindak Pidana Pencucian Uang, yakni korupsi, penyuapan, narkotika dan psikotropika, penyelundupan tenaga kerja, penyelundupan migran, tindak pidana di bidang perbankan, tindak pidana di bidang pasar modal, tindak pidana di bidang perasuransian, kepabeanan, cukai, perdagangan orang, perdagangan senjata gelap, terorisme, penculikan, pencurian, penggelapan, penipuan, pemalsuan uang, perjudian, prostitusi, tindak pidana di bidang perpajakan, tindak pidana di bidang kehutanan, tindak pidana di bidang lingkungan hidup, tindak pidana di bidang kelautan dan perikanan, atau tindak pidana lain yang diancam dengan pidana penjara 4 (empat) tahun atau lebih.

Menurut penulis, pihak perusahaan jasa keuangan harus tegas dalam penerapan prinsip mengenal nasabah ini oleh karena berkaitan dengan suatu bentuk tindak pidana. Jika pihak perusahaan jasa keuangan tidak tegas, maka pastinya akan menjadi celah terhadap terjadinya suatu tindak pidana pencucian uang. Tidak 
dapat dipungkiri bahwa perusahaan jasa keuangan berada pada posisi yang dilema dimana di satu sisi diwajibkan untuk menerapkan prinsip mengenal nasabah dan di sisi lain perusahaan jasa keuangan, khususnya perusahaan asuransi sangat membutuhkan kehadiran nasabah pada perusahaannya. Penerapan prinsip mengenal nasabah yang dituangkan dalam Pedoman dan SOP secara sepintas memberikan batasan-batasan tersendiri pada kebutuhan akan nasabah bagi perusahaan jasa keuangan (khususnya perusahaan asuransi) karena penerapan prinsip mengenal nasabah ini selayaknya menyeleksi orang atau badan hukum yang akan menjadi nasabah pada perusahaan jasa keuangan, khususnya perusahaan asuransi. Sedangkan di sisi lain, kebutuhan perusahaan asuransi akan kehadiran nasabah sangat dibutuhkan pula untuk berjalannya perusahaan tersebut.

Penulis berpandangan bahwa penerapan Prinsip Mengenal Nasabah ini yang diimplementasikan dalam bentuk pedoman dan/atau SOP tidaklah membatasi perusahaan asuransi untuk menerima nasabah. Prinsip Mengenal Nasabah ini justru menjadi alat untuk memantau secara legal transaksi-transaksi nasabahnya sehingga segala kegiatan yang dapat diindikasikan sebagai kegiatan pencucian uang dapat dicegah atau ditanggulangi. Untuk itu, maka sangat penting bagi perusahaan asuransi untuk menerapkan prinsip ini. Prinsip ini bukanlah pembatas bagi perusahaan asuransi dengan kebutuhan akan nasabah, namun menjadi instrumen untuk memfilter dan memantau calon nasabah dan atau nasabahnya.

Apabila perusahaan asuransi menerapkan Prinsip Mengenal Nasabah dengan baik, mereka akan dapat mengidentifikasi transaksi keuangan yang mencurigakan yang melibatkan nasabah mereka. Sebuah transaksi yang mencurigakan terjadi ketika seorang nasabah melakukan atau membatalkan transaksi keuangan dengan menggunakan harta yang diduga kuat (reasonably suspected) berasal dari hasil kejahatan. Transaksi keuangan mencurigakan juga terjadi jika transaksi keuangan nasabah menyimpang dari pola transaksi normal nasabah. Perusahaan asuransi diwajibkan melaporkan transaksi mencurigakan kepada PPATK. Mereka juga harus melaporkan transaksi keuangan tunai berjumlah Rp. 500.000.000,- (lima ratus juta rupiah) atau lebih dalam 1 (satu) hari. Penerapan Prinsip Mengenal Nasabah ini sesungguhnya dapat digunakan untuk mengatasi kelemahan penegakan hukum kepada aktor intelektual pencucian uang. Prinsip ini memberikan kemudahan akses terhadap data keuangan nasabah yang diduga melakukan kegitan pencucian uang. Kerahasiaan nasabah tidak berlaku jika nasabah dilaporkan oleh perusahaan jasa keuangan (khususnya perusahaan asuransi) berkaitan dengan kewajiban mereka kepada PPATK ataupun diduga terlibat kasus pencucian uang. Selain itu, penegak hukum dan hakim dapat langsung meminta data keuangan kepada perusahaan jasa keuangan (khususnya perusahaan asuransi) yang bersangkutan tentang pihak terlapor, tersangka, atau terdakwa.

Di samping itu, dengan adanya prinsip mengenal nasabah ini, maka tidak perlu lagi menunggu keputusan pengadilan untuk membuka data nasabah dan membekukan simpanan tersangka atau terdakwa di perusahaan jasa keuangan (khususnya perusahaan asuransi) yang bersangkutan. Penegak hukum tidak perlu membuktikan terlebih dahulu adanya tindak pidana asal (predicate offence). Penerapan prinsip mengenal nasabah ini dapat memberikan perlindungan hukum kepada pihak pelapor dan saksi kasus pencucian uang. Prosedur perlindungan pelapor dan saksi dapat berbentuk menyembunyikan identitas saksi dan tidak mempertemukan saksi atau pelapor dengan tersangka.

Perlindungan hukum bagi perusahaan jasa keuangan, (termasuk perusahaan asuransi) dalam hal terjadinya kegiatan pencucian uang sudah tercermin dalam Peraturan Pemerintah Nomor 57 Tahun 2003 tentang Tata Cara Perlindungan Khusus Bagi Pelapor dan Saksi Tindak Pidana Pencucian Uang. Setiap perusahaan jasa keuangan non bank, termasuk perusahaan asuransi diberikan kewajiban 
mendokumentasikan dan memberikan laporan atas transaksi yang tidak wajar yang dilakukan oleh nasabahnya kepada PPATK sebagaimana diatur dalam Pasal 19 ayat (3) dan (4) PMK Nomor 30/PMK.010/2010. Atas laporan yang dimaksud, maka penyidik, penuntut umum, dan hakim juga diwajibkan untuk memberikan perlindungan khusus kepada pelapor dan saksi pada setiap tingkat pemeriksaan perkara sebagaimana diatur dalam Pasal Pasal 3 Peraturan Pemerintah Nomor 57 Tahun 2003.

Di dalam Pasal 2 Peraturan Pemerintah Nomor 57 Tahun 2003 juga diatur:

(1) Setiap pelapor dan saksi dalam perkara tindak pidana pencucian uang wajib diberikan perlindungan khusus, baik sebelum, selama maupun sesudah proses pemeriksaan perkara.

(2) Perlindungan khusus sebagaimana dimaksud dala ayat (1) dilaksanakan oleh Kepolisian Negara Republik Indonesia.

Adapun bentuk perlindungan khusus yang dimaksudkan di atas diuraikan dalam Pasal 5 Peraturan Pemerintah Nomor 57 Tahun 2003, yakni sebagai berikut:

1. Perlindungan atas keamanan pribadi, dan atau keluarga pelapor dan saksi dari ancaman fisik atau mental;

2. Perlindungan terhadap harta pelapor dan saksi;

3. Perahasiaan dan penyamaran identitas pelapor dan saksi; dan/atau

4. Pemberian keterangan tanpa bertatap muka dengan tersangka atau terdakwa pada setiap tingkat pemeriksaan perkara.

Perlindungan atas keamanan pribadi, dan/atau keluarga Pelapor dan Saksi dari ancaman fisik atau mental sebagaimana dimaksud pada poin 1 di atas dapat diberikan misalnya dalam bentuk penjagaan fisik yang dilakukan untuk jangka waktu tertentu, evakuasi atau relokasi Pelapor dan Saksi ke tempat lain yang aman dan bebas dari ancaman. Kemudian yang dimaksud dengan perahasiaan sebagaimana dimaksud pada poin 3 di atas misalnya tidak menyebutkan sama sekali identitas Pelapor dan Saksi, sedangkan Penyamaran misalnya dilakukan dengan menyebut identitas lain dari Pelapor dan Saksi.

Dalam konteks kegiatan pencucian uang, penerapan prinsip mengenal nasabah menurut penulis merupakan bentuk perlindungan hukum yang preventif sebagai upaya untuk mencegah terjadinya kegiatan pencucian uang pada perusahaan jasa keuangan. Hal ini dapat dilihat dari proses pengidentifikasian calon nasabah yang cukup ketat yang diwajibkan kepada perusahaan jasa keuangan, khususnya perusahaan asuransi dalam merekrut calon nasabah.

Bukan hanya itu saja, bahkan setelah menjadi nasabah, yang bersangkutan akan terus dipantau setiap transaksi yang dilakukannya. Jika terjadi transaksi yang mencurigakan sebagaimana indikator yang telah ditentukan, maka yang bersangkutan akan diindikasikan melakukan kegiatan pencucian uang. Dalam konteks ini, pihak perusahaan asuransi akan bertindak sebagai pelapor sekaligus sebagai saksi dan dapat memperlihatkan kepada ihak-pihak yang berwenang kejanggalan-kejanggalan dari transaksi yang dilakukan nasabah yang bersangkutan.

\section{PENUTUP}

Penerapan Prinsip Mengenal Nasabah (know your customer) pada perusahaan asuransi dilaksanakan berdasarkan Peraturan Menteri Keuangan Nomor 30/PMK.010/2010 tentang Penerapan Prinsip Mengenal Nasabah Bagi Lembaga Keuangan Non Bank dan Peraturan OJK Nomor Nomor 12 /POJK.01/2017 tentang Penerapan Program Anti Pencucian Uang dan Pencegahan Pendanaan Terorisme Di Sektor Jasa Keuangan yang kemudian dikuatkan dengan adanya Keputusan Kepala Pusat Pelaporan dan Analisis Transaksi Keuangan Nomor 2/1/KEP.PPATK/2003 tentang Pedoman Umum Pencegahan dan Pemberantasan Tindak Pidana Pencucian Uang Bagi Penyedia Jasa Keuangan dan Peraturan Ketua Badan Pengawas Pasar Modal dan Lembaga Keuangan (Bapepam dan LK) Nomor Per-01/BL 2011 tentang 
Pedoman Pelaksanaan Prinsip Mengenal Nasabah Bagi Perusahaan Perasuransian. Setiap perusahaan asuransi diwajibkan untuk membuat Pedoman dan SOP Pelaksanaan Prinsip Mengenal Nasabah untuk mengetahui dan menganalisis calon nasabahnya dan memantau transaksi-transaksi yang dilakukan oleh nasabahnya.

Perlindungan hukum bagi perusahaan asuransi pada kegiatan pencucian uang sesungguhnya sudah tercermin dalam Peraturan Pemerintah Nomor 57 Tahun 2003 tentang Tata Cara Perlindungan Khusus Bagi Pelapor dan Saksi Tindak Pidana Pencucian Uang. Penerapan Prinsip Mengenal Nasabah merupakan bentuk perlindungan hukum yang preventif sebagai upaya untuk mencegah terjadinya kegiatan pencucian uang pada perusahaan jasa keuangan. Hal ini dapat dilihat dari proses pengidentifikasian calon nasabah yang cukup ketat yang diwajibkan kepada perusahaan jasa keuangan, khususnya perusahaan asuransi dalam merekrut calon nasabah. Bukan hanya itu saja, bahkan setelah menjadi nasabah, yang bersangkutan akan terus dipantau setiap transaksi yang dilakukannya. Jika terjadi transaksi yang mencurigakan sebagaimana indikator yang telah ditentukan, maka yang bersangkutan akan diindikasikan melakukan kegiatan pencucian uang.

\section{DAFTAR PUSTAKA}

Ade Irma Junida dan Suryanto, Pencucian Uang Berkedok Polis Asuransi Rp. 11,4 Miliar, sumber:

https://www.antaranews.com/berita/402794/pencucian-uang-berkedokpolis-asuransi-rp114-miliar

Adi, Trend Pencucian Uang Dengan Modus Asuransi, sumber: http:/ / bandung. bisnis.com/read/20131119/2463/458478/trenpencucian-uang-dengan-modus-asuransi\#

Gusti Grehenson, Trend Modus Pencucian Uang Gunakan Identitas Palsu di Perbankan Kian Meningkat, sumber: https://ugm.ac.id/id/berita/582trend.modus.pencucian.uang.gunakan.identitas.palsu.di.perbankan.kian.m eningkat

Priyambodo, RH., Kejahatan Perbankan Gunakan Modus Pencucian Uang, sumber: https://www.antaranews.com/berita/258544/kejahatan-perbankangunakan-modus-pencucian-uang

Sutan Remy Sjahdeini, 2004, Seluk Belum Tindak Pidana Pencucian Uang dan Pembiayaan Terorisme, Grafiti, Jakarta.

Yunus Husein, Bunga Rampai Anti Pencucian Uang, Book Terrace \& Library, Jakarta, 2007. 